\title{
Chinese origin and radiation of the Palaeozoic Crinoid Family Petalocrinidae
}

Ying-Yan Mao a, b, Jih-Pai Lin ${ }^{\mathrm{c},}$ *, Cai-Hua Lin ${ }^{\text {a }}$, William I. Ausich ${ }^{\mathrm{d}}$

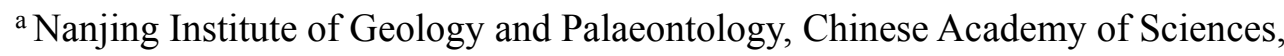
Nanjing 210008, China

${ }^{\mathrm{b}}$ University of the Chinese Academy of Sciences, Beijing 100049, China

${ }^{\mathrm{c}}$ State Key Laboratory of Palaeobiology and Stratigraphy, Nanjing Institute of Geology and Palaeontology, Chinese Academy of Sciences, Nanjing 210008, China

d School of Earth Sciences, The Ohio State University, Columbus, Ohio 43210, USA

\begin{abstract}
The Ordovician to Devonian family Petalocrinidae includes 28 species belonging to 5 genera. This family is unique because the arm plates are fused into a large fan or cylinder. Paleobiogeographic occurrences of this family include Laurentia, Baltica, Avalonia, South China, Sibumasu, and Perunica blocks. The family has the oldest petalocrinids from China. An early radiation of this clade resulted in three genera during the Llandovery of China. Petalocrinus became cosmopolitan during the Llandovery and Wenlock, and the youngest genus is present in the Lower Devonian of the Czech Republic. Taxonomic determination for the Petalocrinidae is based on the fused arm plates instead of cup plates. The diverse morphology of these arm plates suggests a variety of aerosol suspension-feeding modes may have been used by petalocrinids.
\end{abstract}

Keywords: Crinoidea; Eopetalocrinus; Petalocrinus; Vadarocrinus; Paleozoic; South China

\footnotetext{
* Corresponding author at: Department of Geosciences, National Taiwan University, P.O. Box 13-318, Taipei 106, Taiwan. Tel.: +886 2-33662918; fax: +886 2-23636095. E-mail addresses: jplin@hotmail.com (J.P. Lin)
} 


\section{Introduction}

Large, isolated, fan-shaped plates with bifurcating grooves from the Silurian of Gotland, Sweden, were considered to be crinoidal remains by F.A. Bather (Bather, 1898), but their affinity was sufficiently problematic that he did not discuss them in his 1893 study (see Bather, 1893). With the description of Petalocrinus mirabilis Weller and Davidson (1896) (in the new genus Petalocrinus), the anatomy of this most unusual crinoid was finally understood. In addition to isolated fan-shaped plates, Weller and Davidson described two complete specimens, each with five fan-shaped arms radiating from a small, subspherical aboral cup (in oral view). In P. mirabilis, each arm consists of two plates. The first arm plate is a typical, rectilinear brachial plate, but the remainder of the arm is one large, subtriangular plate that contains an ambulacrum that bifurcates numerous times. This crinoid was sufficiently distinctive that Weller and Davidson (1896) also erected the Petalocrinidae for their new species. In contrast to Petalocrinus, other genera of the Petalocrinidae are relatively poorly understood.

Unfortunately, Spirocrinus $\mathrm{Mu}$ and Wu, 1974 was not included in the Treatise on Invertebrate Paleontology (Lane and Moore, 1978). Subsequently, three additional petalocrinid genera have been described: Vadarocrinus Prokop, 1984 (Lower Devonian, Czech Republic); Sinopetalocrinus Mu and Lin, 1987 (lower Silurian, China); and Eopetalocrinus Li, 1993 (Ordovician, China). In this contribution, we present objective diagnoses for genera in the Petalocrinidae and summarize the geographic, paleoecologic, and evolutionary history of this fascinating crinoid family.

\section{History of study}

A total of 28 species belonging to five genera are assigned to the Petalocrinidae (Table 1) (Fig. 1). The family was first proposed by Weller and Davidson (1896), who described articulated specimens of Petalocrinus mirabilis from the Hopkinton Dolomite of Iowa (Llandovery), which resembled a flower with five petals when fully expanded. Bather (1898) reviewed the history, geological relations, anatomical description, systematics, and the affinities of six species of Petalocrinus, and he 
recognized this taxon as a dicyclic cladid rather than a monocyclic crinoid (Fig. 1C).

Occurrences of Petalocrinus in China were first documented by Mu (1950), who recognized two new species on the basis of the specimens from the Shihniulan Limestone (Llandovery) at Wuchuan, Guizhou Province. In 1974, Mu and Wu described the new genus Spirocrinus from the Leijiatum Formation (Llandovery) in the same province. Prokop (1984) reported a new genus of this family from the Koněprusy Limestone (Lower Devonian, Pragian) on the basis of a single specimen, which was the first record of the Petalocrinidae from the Czech Republic. Mu and Lin (1987) described numerous petalocrinids from China, including the new genus Sinopetalocrinus. Finally, Li (1993) reported two specimens from the Dawan Formation (now called Zitai Formation in this region; Zhang et al., 2002; Chen and Zhan, 2006; Wu et al., 2007; Zhang, 2009) (Floian-Darriwilian, Ordovician; Hubei Province, China) and named a new genus Eopetalocrinus. Because Eopetalocrinus is the oldest record of the family, Li (1993) hypothesized potential evolution trends among Eopetalocrinus, Petalocrinus, Sinopetalocrinus, and Spirocrinus in South China. Significantly, Fearnhead and Donovan (2007) reported new articulated specimens of Petalocrinus from the British Isles, confirming the crown morphology of this genus.

\section{Petalocrinidae evolutionary history}

Today, the Petalocrinidae is known from the Ordovician (Floian-Darriwilian) through the Early Devonian (Pragian) (Fig. 2). Petalocrinus is now recognized as having a cosmopolitan distribution during the Llandovery and Wenlock, as noted by Witzke et al. (1979). However, the significance of China for petalocrinid evolutionary history was not fully understood until the work of Mu and Lin (1987) and Li (1993), who described three new Chinese petalocrinid genera that ranged in age from the Ordovician through the early Silurian.

The Petalocrinidae presumably originated on the South China Block during the Ordovician (Floian-Darriwilian) with the appearance of Eopetalocrinus. Li (1993) hypothesized that three new petalocrinids evolved in China during the Silurian from 
this initial stock, including Petalocrinus, Sinopetalocrinus, and Spirocrinus. The oldest petalocrinid outside of China is Petalocrinus sp. cf. P. visbyensis from the Mulloch Hill Formation (Rhuddianian; Llandovery; Fearnhead and Harper, 2007) of Scotland (Laurentia) (Fig. 2). However, by at least the late Llandovery Petalocrinus had migrated to Avalonia and Baltica. The youngest members of Petalocrinus are from the Wenlock of Laurentia (P. longus, Indiana, USA) and Baltica (P. visbyensis, Sweden). Finally, the youngest petalocrinid is Vadarocrinus, which is only known from the Early Devonian of Perunica (Czech Republic).

In general, the Ordovician was characterized by endemic faunas (Paul, 1976; Lefebvre et al., 2013), whereas the Silurian had more cosmopolitan faunas (Witzke et al., 1979; Cocks and Fortey, 1990). The global distribution of Petalocrinus was earlier than the typical cosmopolitan Wenlock faunas (Witzke et al., 1979).

A glacial epoch began during the late Ordovician and continued through the Llandovery (Grahn and Caputo, 1992; Brenchley et al., 1994, 2003; Ghienne, 2003; Ghienne et al., 2007; Schönian and Egenhoff, 2007; Gutiérrez-Marco et al., 2010). Sea level rose significantly during Llandovery interglacials, as evidenced by widespread carbonates in eastern Laurentia (e.g., Brassfield Limestone, Ohio; Hopkinton Dolomite, Iowa), and Petalocrinus must have migrated globally during a Llandovery interglacial. As suggested by Fearnhead and Harper (2007), the geographic distribution of Petalocrinus may be indicative of geographic proximity of tectonic blocks within a sub-equatorial distribution.

\section{Feeding paleoecology of the Petalocrinidae}

The unique aspect of this family is the fused arm plates, and this has attracted speculation on the function of the arms during life. Living crinoids, and, by inference, extinct stalked crinoids, are adapted to rheophilic feeding as passive, epifaunal suspension feeders that employed aerosol suspension feeding (see Ausich, 1980; Ausich et al., 1999). As such, crinoids with different filtration fan densities were adapted to preferentially capture food particles of different sizes.

Interpretative drawings of Petalocrinus in life position were first constructed by 
Ubaghs (1953, fig. 85), then reproduced subsequently (Tien and Mu, 1955, text-fig. 31; Müller, 1963, fig. 463; Moore and Jeffords, 1968, fig. 5.2; Fearnhead and Donovan, 2007, text-fig. 5; Prokop and Petr, 2010, fig. 1), and followed by Frest and Strimple (1977, text-fig. 2). Furthermore, Prokop and Petr (2010, fig. 2) used this as a model and modified it for their Devonian form. All of these reconstructions position the five arms as if they were an umbrella, thus in a position to capture particles falling vertically from the water column. This is undoubtedly an unrealistic reconstruction, because, as is known, crinoids are typically adapted to unidirectional currents with the filtration fan positioned more-or-less vertically when feeding, thus perpendicular to the current. Further, modern crinoids in this posture typically have the tips of the arms bent back into the current to produce a parabolic filtration fan (Macurda and Meyer, 1974), which has been shown to be more efficient in particle capture compared to a planar fan (Warner, 1977). Interestingly, the arched morphology of the fused arm plates of some petalocrinids (Fig. 1D) resulted in an obligate parabolic shape for the overall filtration fan. Better preserved and articulated specimens are needed in order to fully assess feeding posture hypotheses; however, it is much more probable that the petalocrinid feeding posture was more like that of other stalked crinoids. It should have only assumed the umbrella posture in slack currents.

In typical crinoids, currents pass through and eddy around the arms, and particle capture was either by direct interception on the aboral side of the arms or on the oral side from currents eddying around the arms (Rubenstein and Koehl, 1977; Ausich, 1980). The petalocrinids deviated from this basic model. On the solidly plated arms of Eopetalocrinus, Petalocrinus, and Vadarocrinus, feeding must have been accomplished primarily from currents eddying around from the aboral to the oral side of the filtration fan. Feeding from direct interception could have only occurred along the distal margin of the fused arms. Sinopetalocrinus had ambulacra on both the oral and aboral sides of the solid arm plates, so that food capture could have occurred both by direct interception on most of the aboral side of the arms and from eddy currents on the oral side of the arms. In contrast, Spirocrinus had ambulacra spiraled around a cylindrical fused arm. Their filtration fan was very open, and food capture could have 
occurred from any direction. A modern analog may be the multidirectional filtration fan posture of some comatulid crinoids that live in reefal environments with multidirectional currents (Meyer, 1979). Interestingly, one could argue from a filtration fan and feeding perspective that Sinopetalocrinus and Spirocrinus had more optimal feeding designs. Yet, Petalocrinus was ultimately the most successful genus of the Petalocrinidae.

\section{Systematic paleontology}

Class CRINOIDEA Miller, 1821

Subclass CLADIDA Moore and Laudon, 1943

Order CYATHOCRININA Bather, 1899

Superfamily GASTEROCOMACEA Roemer, 1854

Family PETALOCRINIDAE Weller and Davidson, 1896

Remarks: The Petalocrinidae is a unique crinoid family with each arm being entirely (or primarily) a single plate. The assumption by all previous authors was that this plate represents the fusion of numerous brachial plates. This assumption is probably correct. However, the alternative hypothesis is that the arm plate is the expansion of a single brachial plate, and this alternative has not been falsified.

Arm fragments, especially those of Vadarocrinus, may superficially look like species of Gissocrinus with greatly widened brachials (e.g., G. magnibrachiatus Springer, 1926, pl. 32, figs. 3-6). However, G. magnibrachiatus has axillary brachials with a single bifurcation of the ambulacrum, and their non-axillary brachials contain a single, straight ambulacrum. This contrasts with petalocrinids that have multiple bifurcations on the single arm plate.

In general, Petalocrinus has a relatively small aboral cup with five fused arm plates. These characteristic arm plates are robust and can be transported after death as isolated plates. Unusual among crinoids, the genera and species of the Petalocrinidae are based primarily on the fused arm plates instead of aboral cup plates (Fearnheard and Donovan, 2007). A diagnostic table is included for quick identification at the 
generic level (Table 2).

Genus Petalocrinus Weller and Davidson, 1896

Type species: Petalocrinus mirabilis Weller and Davidson, 1896.

Occurrences: Hopkinton Dolomite, Caralline Member, Silurian (Llandovery), Iowa, USA; Scotch Grove Formation, Silurian (Llandovery), Iowa, USA; Buck Creek Member, Scotch Grove Formation, Silurian (Llandovery), Iowa, USA; Sandpile Formation (Laurentian), Silurian (Llandovery-Wenlock), British Columbia, Canada (Norford, 1962); lower Silurian strata, western Yunnan Province, China (Chen and Yao, 1993).

Included species: P. angustus Bather, 1898, Visby Formation (undifferentitated), Silurian (Llandovery-Wenlock), Gotland, Sweden. P. bifidus Donovan and Fearnhead in Fearnhead and Donovan, 2007, Petalocrinus Limestone, Silurian (Llandovery), Scotland, United Kingdom; Haugh Wood Formation, Silurian (Llandovery), United Kingdom. P. chiai Mu, 1950, Leichiatun Formation (approximately age equivalent to Xiangshuyuan Formation and Shihniulan Limestone), Silurian (Llandovery), Guizhou Province, China. P. eximius Mu and Wu, 1974, Leichiatum Formation, Silurian (Llandovery), Guizhou Province, China. P. expansus Bather, 1898, Visby Formation (undifferentitated), Silurian, (late Llandovery to Wenlock), Gotland, Sweden. $P$. guizhouensis Mu and Lin, 1987, Xiangyuangsi Formation, Silurian (Llandovery), Guizhou Province, China. P. inferior Bather, 1898, Hopkinton Dolomite, Silurian (Llandovery), Iowa, USA; Laurel Limestone, Silurian (Wenlock), Indiana, USA; Cedarville Limestone, Silurian (Wenlock), Ohio, USA; Shihniulan Limestone, Silurian (Llandovery), Guizhou Province, China; Luoreping Formation, Silurian (Llandovery), Sichuan Province, China; Silurian (Llandovery), Hubei Province, China. P. inflatus Mu, 1950, Shihniulan Formation, Silurian (Llandovery), Guizhou Province, China. P. involucrus Mu and Wu, 1974, Leichiatun Formation, Silurian (Llandovery), Guizhou Province, China. P. latus Mu and Lin, 1987, Xiangyuangsi Formation, Silurian (Llandovery), Guizhou Province, China. P. longus Bather, 1898, Laurel Limestone, Silurian (Wenlock), Indiana, USA. P. magnus Mu and Lin, 1987, 
Xiangyuangsi Formation, Silurian (Llandovery), Guizhou Province, China. P. sinensis

Mu and Wu, 1974, Loureping Group (now Loureping Formation), Silurian

(Llandovery), Hubei Province, China; Xiangyuangsi Formation, Silurian

(Llandovery), Guizhou Province, China. P. tenuis Mu and Lin, 1987, Xiangyuangsi

Formation, Silurian (Llandovery), Guizhou Province, China. P. validus $\mathrm{Mu}$ and $\mathrm{Wu}$, 1974, Leichiatum Group (now Leijiatun Formation; Mu et al., 1986), Silurian

(Llandovery), Guizhou Province, China. P. visbycensis Bather, 1898, Visby

Formation (undifferentitated), Silurian (late Llandovery to Wenlock), Gotland, Sweden; Slite Formation, Silurian (Wenlock), Gotland, Sweden. Petalocrinus sp. cf. P. visbycensis Bather, 1898 in Fearnhead and Harper, 2007, Mulloch Hill Sandstone Formation, Silurian (Llandovery, Aeronian), Scotland, United Kingdom.

Diagnosis: Semicircular-shaped articular facets, fused brachials subtriangular and expanding distally, as many as 32 distal ambulacra, adjacent arms not in lateral contact, ambulacral grooves only on oral surface.

Remarks: This is the most characteristic genus of the family with a worldwide distribution. A total of 17 species has been documented (Table 1). Although articulated specimens have been reported from the USA (Weller and Davidson, 1896; Bather, 1898), United Kingdom (Donovan and Fearnhead, 2007) (Fig. 1B, C), and China (Chen and Yao, 1993) (Fig. 3), isolated arm plates are the most common elements preserved in the fossil record (Fig. 1E-G). The ambulacral cover plates are only preserved in a few specimens (see Fig. 1T).

Genus Eopetalocrinus Li, 1993

Type species: Eopetalocrinus sinensis Li, 1993.

Occurrences: Zitai Formation (age equivalent to the Dawan Formation), Ordovician (Floian-Darriwilian), Hubei Province, China.

Diagnosis: Fusiform-shaped articular facets and forming a sub-pentagonal, fused brachials subtriangular and expanding distally, 18-29 distal ambulacra, adjacent arms in lateral contact, ambulacral grooves only on oral surface.

Remarks: This is the earliest occurrence of the family. The reported specimens were 
deposited at the Yangtze University (JHJ). Due to the relocation of the university, the type and figured specimens of $E$. sinensis were lost. Nevertheless, published figures and drawings are of good quality (see Fig. 1A), and an ongoing priority is to collect new topotype material and to designate a neotype. A recent visit indicated that the fossil section is dominated by reddish limestones; thus, it is best to call it the Zitai Formation instead of Dawan Formation, which is richer in yellow-green limestones (Chen and Zhan, 2006). Currently, the age of the unit (Zitai or Dawan Formation) ranges from Floian to Darriwilian (Wu et al., 2007); however, echinoderm ossicles are relatively common in the middle portion of the unit based on the field observation, and thus the approximate age for Eopetalocrinus is Dapingian (Fig. 2).

Genus Sinopetalocrinus Mu and Lin, 1987

Type species: Sinopetalocrinus involutus Mu and Lin, 1987.

Occurrences: Leijiatun Formation, Silurian (Llandovery, Aeronian), Guizhou Province, China.

Other species: S. robustus Mu and Lin, 1987, Leijiatun Formation, Silurian

(Llandovery), Guizhou Province, China. S. shiqianensis Mu and Lin, 1987, Leijiatun Formation, Silurian (Llandovery), Guizhou Province, China.

Diagnosis: Horseshoe-shaped articular facets; fused brachials expand in width rapidly for short distance, then are parallel sided and finally a convex distal margin; as many as 40 distal ambulacra, adjacent arms not in lateral contact, ambulacral grooves on oral and aboral surface.

Remarks: This genus is endemic to Silurian strata of South China (Mu and Lin, 1987). A total of three species has been documented (Table 1) (Fig. 1I-M).

Genus Spirocrinus Mu and Wu, 1974

Type species: Spirocrinus typicus $\mathrm{Mu}$ and $\mathrm{Wu}, 1974$.

Occurrences: Leijiatun Formation, Silurian (Llandovery), Guizhou Province, China.

Other species: S. abnormis $\mathrm{Mu}$ and Lin, 1987, Leijiatun Formation, Silurian (Llandovery), Guizhou Province, China. S. longus $\mathrm{Mu}$ and Wu, 1974, Leijiatun 
Formation, Silurian (Llandovery), Guizhou Province, China. S. multiramus $\mathrm{Mu}$ and Lin, 1987, Leijiatun Formation, Silurian (Llandovery), Guizhou Province, China. $S$. pauciramus Mu and Lin, 1987, Leijiatun Formation, Silurian (Llandovery), Guizhou Province, China. S. uniformis $\mathrm{Mu}$ and Lin, 1987, Leijiatun Formation, Silurian (Llandovery), Guizhou Province, China.

Diagnosis: Horseshoe-shaped articular facets, fused brachials cylindrical and tapered at both ends, as many as 10-12 distal ambulacra, adjacent arms not in lateral contact, ambulacral grooves spiraled around fused arm with left-hand spiral.

Remarks: This is endemic to Silurian strata in the South China block ( $\mathrm{Mu}$ and $\mathrm{Wu}$, 1974; Mu and Lin, 1987; Mao et al., 2013). A total of six species has been documented (Table 1) (Fig. 1N-P).

Genus Vadarocrinus Prokop, 1984

Type species: Vadarocrinus vassa Prokop, 1984.

Occurrences: Koněprusy Limestone, Devonian (Pragian), Bohemia, Czech Republic; Lodenice Limestone, Devonian (Pragian), Bohemia, Czech Republic.

Diagnosis: Broad and smooth articular facets, fused brachials subtriangular and expanding distally, number of distal ambulacra unknown, adjacent arms not in lateral contact, ambulacral grooves only on oral surface.

Remarks: This species was reported originally from one specimen (Prokop, 1984)

(Fig. 1Q-S). Subsequently, eight additional specimens were recovered from the type locality (Prokop and Petr, 2010). This is the only known occurrence of the genus (and the family) in both the Devonian and the Perunica microcontinent.

\section{Conclusion}

In the Treatise, the family Petalocrinidae was only represented by one genus with a wide distribution during the middle Silurian (Keim, 1978, p. 383; Lane and Moore, 1978, fig. 371). Presently, the family contains five genera, ranging from Ordovician to Lower Devonian. Previously, many workers had hypothesized on the origin of this family. Based on the facts that the South China block contains both the oldest 
occurrences of the family and most diversified forms (four genera, whereas other paleocontinents only have one genus), China is the key origination center for the Petalocrinidae. Despite arms consisted of fused plates, feeding probably occurred with several modes of aerosol suspension feeding.

\section{Acknowledgements}

T.W. Kammer and E. Rhenberg are thanked for their constructive comments. This work was supported by the National Science Foundation of China (41372022, J1210006); State Key Laboratory of Palaeobiology and Stratigraphy (20131103); the National Science Foundation (DEB 1036416). Many thanks to Xiao-Ping Zhang for finding key references; Dao-Jun Yuan for the access to the type and figured specimens at NIGPAS; T. Ewin, J. Darrell, F. Fearnhead for the access to figured specimens at BMNH; Professor Yue Li and his students for field assistance. This is a part of the M.S. thesis project for Mao.

\section{References}

Ausich, W.I., 1980. A model for niche differentiation in Lower Mississippian crinoid communities. Journal of Paleontology 54, 273-288.

Ausich, W.I., Brett, C.E., Hess, H., Simms, M.J., 1999. Crinoid form and function. In: Hess, H., Ausich, W.I., Brett, C.E., Simms, M.J. (Eds.), Fossil Crinoids. Cambridge University Press, Cambridge, pp. 3-30.

Bather, F.A., 1893. The Crinoidea of Gotland. Pt. 1, The Crinoidea Inadunata. Kongliga Svenska Vetenskaps-Akademiens Handlingar 25 (2), 1-200.

Bather, F.A., 1898. Petalocrinus, Weller \& Davidson. The Quarterly Journal of the Geological Society of London 54 (1-4), 401-441.

Bather, F.A., 1899. A phylogenetic classification of the Pelmatozoa. British Association for the Advancement of Science 1898, 916-923.

Brenchley, P.J., Marshall, J.D., Carden, G.A.F., Robertson, D.B.R., Long, D.G.F., Meidla, T., Hints, L., Anderson, T.F., 1994. Bathymetric and isotopic evidence for a shortlived Late Ordovician glaciation in a greenhouse period. Geology 22, 295-298. 
Brenchley, P.J., Carden, G.A.F., Hints, L., Kaljo, D., Marshall, J.D., Martma, T., Meidla, T., Nolvak, J., 2003. High-resolution stable isotope stratigraphy of Upper Ordovician sequences: constraints on the timing of bioevents and environmental changes associated with mass extinction and glaciation. Geological Society of America Bulletin 115, 89-104.

Chen, P.F., Zhan, R.B., 2006. The Lower to Middle Ordovician Dawan Formation and its coeval rocks in the Yangtze Region. Journal of Stratigraphy 30 (1), 11-20 (in Chinese, with English abstract).

Chen, Z.T., Yao, J.H., 1993. Palaeozoic Echinoderm Fossils of Western Yunnan, China. Geological Publishing House, Beijing, 102 pp. (in Chinese).

Cocks, L.R.M., Fortey, R.A., 1990. Biogeography of Ordovician and Silurian faunas. Geological Society Memoir 12, 97-104.

Fearnhead, F.E., Donovan, S.K., 2007. New crinoids (Echinodermata) from the Llandovery (Lower Silurian) of the British Isles. Palaeontology 50, 905-915.

Fearnhead, F.E., Harper, D.A.T., 2007. Petalocrinus (Echinodermata, Crinoidea) from the Llandovery (Lower Silurian; Rhudannian) of the Girvan district, SW Scotland. Scottish Journal of Geology 43, 69-74.

Frest, T.J., Strimple, H.L., 1977. Hirneacrinidae (new), simple Silurian camerate crinoids from the North American continental interior. Journal of Paleontology, $51(6), 1181-1200$.

Ghienne, J., 2003. Late Ordovician sedimentary environments, glacial cycles, and postglacial transgression in the Taoudeni Basin, West Africa. Palaeogeography, Palaeoclimatology, Palaeoecology 189, 117-145.

Ghienne, J.P., Le Heron, D., Moreau, J., Denis, M., Deynox, M., 2007. The Late Ordovician glacial sedimentary system of the North Gondwana platform. International Association of Sedimentologists Special Publication 39, 295-319.

Grahn, Y., Caputo, M.V., 1992. Early Silurian glaciations in Brazil. Palaeogeography, Palaeoclimatology, Palaeoecology 99, 9-15.

Gutiérrez-Marco, J.C., Ghienne, J.F., Bernárdez, E., Hacar, M.P., 2010. Did the Late Ordovician African ice sheet reach Europe? Geology 38, 279-282. 
Keim, J.D., 1978. Stratigraphic distribution. In: Moore, R.C., Teichert, C. (Eds.), Treatise on Invertebrate Paleontology. Part T. Echinodermata 2. Crinoidea 1. The Geological Society of America and University of Kansas Press, Boulder and Lawrence, pp. 371-401.

Lane, N.G., Moore, R.C., 1978. Suborder Cyathocrinina Bather, 1899. In: Moore, R.C., Teichert, C. (Eds.), Treatise on Invertebrate Paleontology. Part T.

Echinodermata 2. Crinoidea 2. The Geological Society of America and University of Kansas Press, Boulder and Lawrence, pp. 578-606.

Lefebvre, B., Sumrall, C.D., Shroat-Lewis, R.A., Reich, M., Webster, G.D., Hunter, A.W., Nardin, E., Rozhnov, S.V., Guensburg, T.E., Touzeau, A., Noailles, F., Sprinkle, J., 2013. Palaeobiogeography of Ordovician echinoderms. Geological Society of London Memoirs 38, 173-198.

Li, L.Z., 1993. Discovery of Eopetalocrinus (gen. nov.) in Lower Ordovician Dawan Formation at Liujiachang, Songzi, Hubei and its significance. Oil and Gas Geology 14 (4), 272-278 (in Chinese).

Macurda, D.B., Jr., Meyer, D.L., 1974. Feeding posture of modern stalked crinoids. Nature 247, 394-396.

Mao, Y.Y., Lin, J.P., Li, X.F., 2013. New material of Petalocrinidae from northern Guizhou. Acta Geologica Sinica (English Edition) 87 (Supp.), 886-888.

Meyer, D.L., 1979. Length and spacing of tube feet in crinoids (Echinodermta) and their role in suspension-feeding. Marine Biology 51, 361-369.

Miller, J.S., 1821. A Natural History of the Crinoidea, or Lily-shaped Animals; with Observations on the Genera, Asteria, Euryale, Comatula and Marsupites. Bryan \& Co., Bristol, $150 \mathrm{pp}$.

Moore, R.C., Jeffords, R.M., 1968. Classification and nomenclature of fossil crinoids based on studies of dissociated parts of their columns. University of Kansas Paleontological Contributions, Echinodermata Article 9, 1-86.

Moore, R.C., Laudon, L.R., 1943. Evolution and classification of Paleozoic crinoids. Geological Society of America Special Paper 46, 1-151.

Mu, A.T., 1950 [1949]. Petalocrinus from the Shihniulan Limestone of Wuchuan. 
Bulletin of the Geological Society of China 29 (1-4), 93-96.

Mu, A.T., Wu, Y.R., 1974. Silurian Crinoidea. In: Nanjing Institute of Geology and Palaeontology of Chinese Academy of Sciences (Ed.), A Handbook of the Stratigraphy and Palaeontology of Southwest China. Science Press, Beijing, pp. 208-210 (in Chinese).

Mu, A.T., Boucot, A.J., Chu, X., Rong, J.Y., 1986. Correlation of the Silurian rocks of China. Geological Society of America Special Paper 202, 1-80.

Mu, E.Z. [Mu, A.T.], Lin, C.H., 1987. Petalocrinidae from the Silurian of Shiqian District, Guizhou. Bulletin of Nanjing Institute of Geology and Palaeontology 12, 1-30 (in Chinese).

Müller, A.H., 1963 [Reprinted in 1989]. Klasse Crinoidea Miller 1821. In: Müller, A.H. (Ed.), Lehrbuch der Palaozoologie Band II Invertebraten Teil 3 Arthropoda 2 - Hemichordata. Veb Gustav Fischer Verlag, Jena, pp. 351-435.

Norford, B.S., 1962. The Silurian fauna of the Sandpile Group of northern British Columbia. Bulletin of the Geological Survey of Canada 78, 25-26.

Paul, C.R.C., 1976. Palaeogeography of primitive echinoderms in the Ordovician. In: Bassett, M.G. (Ed.), The Ordovician System: Proceedings of a Palaeontological Association Symposium. University of Wales Press, Cardiff, Wales, pp. 553-574. Prokop, R.J., 1984 [1983]. Vadarocrinus vassa gen. et sp. n., (Crinoidea, Petalocrinidae) from the Lower Devonian of Bohemia. Časopis Národního Muzea, Řada Př́rodovědná 152, 187-188.

Prokop, R.J., Petr, V., 2010. New finds of Vadarocrinus vassa Prokop, 1984 (Crinoidea, Petalocrinidae) in the Koněprusy and Loděnice Limestones (Lower Devonian, Pragian) of the Barrandian area, Czech Republic. Journal of the National Museum (Prague), Natural History Series 179 (14), 147-152. Roemer, C.F., 1852-1854. Erste Periode, Kohlen-Gebirge. In: Bronn, H.G. (Ed.), Lethaea Geognostica 1851-1856, Third Edition, Volume Two. E. Schweizerbart, Stuttgart, pp. 210-291.

Rubenstein, D.I., Koehl, M.A.R., 1977. The mechanisms of filter feeding: some theoretical considerations. The American Naturalist 111, 981-994. 
Schönian, F., Egenhoff, S.O., 2007. A Late Ordovician ice sheet in South America: evidence from the Cancañiri tillites, southern Bolivia. Geological Society of America Special Paper 423, 525-548.

Springer, F., 1926. American Silurian Crinoids. Smithsonian Institution Publication $2872,1-239$.

Tien, C.C., Mu, A.T., 1955 [Second printing in 1957]. Crinoidea. In: Chen, X. and others (Eds.), Index Fossils of China, Invertebrates, Volume One. Geological Publishing House, Beijing, pp. 89-95 (in Chinese).

Ubaghs, G., 1953. Classe des crïnoides. In: Piveteau, J. (Ed.), Traitéde Paléontologie Tome III. Masson et Cie, Paris, pp. 658-773.

Warner, G.F., 1977. On the shapes of passive suspension feeders. In: Keegan, B.F., Ceidigh, P.O., Boarder, P.J.S. (Eds.), Biology of Benthic Organisms. Pergamon Press, New York, pp. 567-576.

Weller, S., Davidson, A.D., 1896. Petalocrinus mirabilis (n. sp.) and a new American fauna. The Journal of Geology 4 (2), 166-173.

Witzke, B.J., Frest, T.J., Strimple, H.L., 1979. Biogeography of the Silurian-Lower Devonian echinoderms. In: Gray, J., Boucot, A.J. (Ed.), Historical Biogeography, Plate Tectonics and the Changing Environment. Oregon State University Press, Corvallis, pp. 117-129.

Wu, R.C., Zhan, R.B., Li, G.P., Liu, J.B., 2007. Brief discussion on the Lower to Middle Ordovician Zitai Formation in the Yangtze Region, South China. Journal of Stratigraphy 31 (4), 325-332 (in Chinese, with English abstract).

Zhang, S.X. (Ed.), 2009. Geological Formation Names of China (1866-2000). Higher Education Press and Springer-Verlag, Beijing and Berlin, 1537 pp.

Zhang, Y.B., Zhou, Z.Y., Zhang, J.M., 2002. Sedimentary differentiation during the latest early Ordovician - earliest Darriwilian in the Yangtze Block. Journal of Stratigraphy 26 (4), 302-314 (in Chinese, with English abstract). 


\section{Table and figure captions}

Table 1. List of known species of Petalocrinidae.

Table 2. Diagnostic table for the Petalocrinidae.

Fig. 1. Representatives of five genera of Petalocrinidea, All scale bars $=1 \mathrm{~cm}$. (A) Eopetalocrinus Li, 1993 (JHJ-0001), Dawan Formation (Floian-Dapingian), Hubei, China; oral side of crown (modified from Li, 1993, pl. 1, fig. 1). (B, C) Petalocrinus bifidus from Fearnhead and Donovan (2007) (BMNH E70060, BMNH E49625), Petalocrinus Limestone (Llandovery), Woolhope Inlier, Herefordshire; (B) oral side of crown; (C) aboral side of crown. (D-H) Petalocrinus inflatus Mu, 1950 (GSC 6887), Shihniulan Limestone (Llandovery), Guizhou, China; (D) lateral view of arm plate (arm-fan of Mu and Lin, 1987); (E) front view of distal furrows; (F) oral side of arm plate; $(\mathrm{G})$ facet view of arm plate; note that the articular facet is horseshoe-shaped; (H) aboral side of arm plate. (I-M) Sinopetalocrinus robustus $\mathrm{Mu}$ and Lin, 1987 (NIGP 73971), Leijiatun Formation (Llandovery), Guizhou, China; (I) lateral view of arm plate (arm-roll of Mu and Lin, 1987); (J) front view of distal furrows; (K) oral side (ventral view) of arm plate; (L) facet view of arm plate; note that the articular facet is horseshoe-shaped; (M) aboral side (dorsal view) of arm plate; note that furrows on the dorsal side. (N-P) Spirocrinus uniformis Mu and Lin, 1987 (NIGP 73990), Leijiatun Formation (Llandovery) of Guizhou, China; (N) front view

of distal furrows; (O) lateral view of arm plate (arm-twine of Mu and Lin, 1987); (P) facet view of arm plate. (Q-S) Vadarocrinus vassa Prokop, 1984 (NML 20040), Koněprusy Limestone (Lower Devonian), Bohemia, Czech (modified from Prokop, 1984, pl. 1, figs. 1-3); (Q) lateral view of arm plate; (R) oral side of arm plate; (S) aboral side of arm plate. (T) Petalocrinus exmimius Mu and Wu, 1974 (NIGP 22901), Leijiatun Formation (Llandovery) of Guizhou, China; ventral view of arm plate with preservation of ambulacral plates. Depositories: Yangtze University (JHJ); Natural History Museum, London (BMNH); Nanjing Institute of Geology and Palaeontology, 
Chinese Academy of Sciences (GSC, NIGP); National Museum in Prague (NML).

Fig. 2. Stratigraphic and paleogeographic distribution of the Petalocrinidae, complied from references listed in Table 1.

Fig. 3. Petalocrinus mirabilis Weller and Davidson, 1896, Renheqiao Formation, Yunnan, China (No. 332; re-deposited at NIGP); aboral side of crown with five arms completely. Scale bar $=0.5 \mathrm{~cm}$. 


\begin{tabular}{|c|c|c|c|c|}
\hline Genus & Species & Distribution & Age & Holotype \\
\hline \multicolumn{5}{|c|}{ Eopetalocrinus } \\
\hline & E. sinensis & South China & Floian-Darriwilian & Li, 1993, text-fig. 2; pl. 1, fig. 1 \\
\hline \multicolumn{5}{|c|}{ Petalocrinus } \\
\hline & P. bifidus & British Isles & Llandovery & Donovan and Fearnhead, 2007, text-fig. 3d \\
\hline & P. chiai & South China & Llandovery & Mu, 1950, text-fig. 3, no. 7 \\
\hline & P. exmimius & South China & Llandovery & Mu and $W u, 1974$, pl. 97 , fig. 32 \\
\hline & P. guizhouensis & South China & Llandovery & Mu and Lin, 1987, pl. 4, fig. 6 \\
\hline & $P$. inferior & USA, South China & Llandovery-Wenlock & Bather, 1898, text-fig. 10; pl. 26, fig. 57 \\
\hline & P. inflatus & South China & Llandovery & Mu, 1950, text-fig. 3, no. 4 \\
\hline & P. involucrus & South China & Llandovery & Mu and Wu, 1974, pl. 97, fig. 27 \\
\hline & P. latus & South China & Llandovery & Mu and Lin, 1987, pl. 4, fig. 3 \\
\hline & P. longus & USA & Wenlock & Bather, 1898 , text-figs. 11,12 ; pl. 26 , fig. 60 \\
\hline & P. magnus & South China & Llandovery & Mu and Lin, 1987, pl. 4 , fig. 5 \\
\hline & P. sinensis & South China & Llandovery & Mu and Wu, 1974, pl. 97, fig. 24 \\
\hline & P. tenuis & South China & Llandovery & Mu and Lin, 1987, pl. 4, fig. 1 \\
\hline & P. validus & South China & Llandovery & Mu and Wu, 1974, pl. 97, fig. 16 \\
\hline & P. visbycensis & Sweden, UK & Llandovery-Wenlock & Bather, 1898, pl. 25, fig. 5 \\
\hline & $\begin{array}{c}P . \text { cf. } P \text {. } \\
\text { visbycensis }\end{array}$ & Scotland, UK & Llandovery & Fearnhead and Harper, 2007, fig. 1a-e* \\
\hline \multicolumn{5}{|c|}{ Sinopetalocrinus } \\
\hline & S. involutus & South China & Llandovery & Mu and Lin, 1987, pl. 5, fig. 5 \\
\hline & S. robustus & South China & Llandovery & Mu and Lin, 1987, pl. 6, fig. 1 \\
\hline & S. shiqianensis & South China & Llandovery & Mu and Lin, 1987, pl. 5, fig. 1 \\
\hline \multicolumn{5}{|c|}{ Spirocrinus } \\
\hline & S. abnormis & South China & Llandovery & Mu and Lin, 1987, pl. 7, fig. 12 \\
\hline & S. longus & South China & Llandovery & Mu and Wu, 1974, pl. 97, fig. 8 \\
\hline & S. multiramus & South China & Llandovery & Mu and Lin, 1987, pl. 7, fig. 15 \\
\hline & S. pauciramus & South China & Llandovery & Mu and Lin, 1987, pl. 7, fig. 1 \\
\hline
\end{tabular}

Llandovery

landovery

SA, South China

uth China

Sibumasu

South China

Sweden, UK

South China

South China

South China

South China
Llandovery
Bather, 1898, pl. 25, fig. 26

Mu, 1950, text-fig. 3, no. 7

er, 1898, text-figs. 13,14 ; pl. 25 , fig. 34

$\mathrm{Mu}, 1950$, text-fig. 3, no. 4

Mu and Wu, 1974, pl. 97, fig. 27

ler and Davidson, 1896, pl. 6, figs. 2-5

p. 97, fig. 24

and Lin, 1987, pl. 4, fig. 1

and $\mathrm{Wu}, 1974$, pl. 97, fig. 16

arnhead and Harper, 2007, fig. 1a-e*

Mu and Lin, 1987, pl. 5, fig. 5

Mu and Lin, 1987, pl. 6, fig. 1

Mu and Lin, 1987, pl. 7, fig. 12

Mu and Lin, 1987, pl. 7, fig. 5 


\begin{tabular}{|c|c|c|c|c|c|}
\hline & Articular Facets & Fused Brachial Shape & $\begin{array}{c}\text { Maximum Number } \\
\text { of Ambulacra }\end{array}$ & $\begin{array}{c}\text { Adjacent Arms in } \\
\text { Lateral Contact }\end{array}$ & $\begin{array}{c}\text { Position of } \\
\text { Ambulacral Groove } \\
\end{array}$ \\
\hline Petalocrinus & Semicircular & $\begin{array}{c}\text { Subtriangular, expand } \\
\text { distally }\end{array}$ & $<\sim 32$ & No & Oral side \\
\hline Eopetalocrinus & $\begin{array}{l}\text { Fusiform-shaped } \\
\text { and forming a } \\
\text { pentagon }\end{array}$ & $\begin{array}{l}\text { Subtriangular, expand } \\
\text { distally }\end{array}$ & $18-29$ & Yes & Oral side \\
\hline Sinopetalocrinus & $\begin{array}{l}\text { Horseshoe } \\
\text { shaped }\end{array}$ & $\begin{array}{l}\text { Subtriangular, rapid } \\
\text { expansion for short } \\
\text { distance, then parallel- } \\
\text { sided }\end{array}$ & $\sim 40$ & No & $\begin{array}{l}\text { Oral and aboral } \\
\text { sides }\end{array}$ \\
\hline Spirocrinus & $\begin{array}{l}\text { Horseshoe } \\
\text { shaped }\end{array}$ & $\begin{array}{l}\text { Cylindridal, tapers at } \\
\text { both ends }\end{array}$ & $\begin{array}{c}\text { 10-12 ambulacral } \\
\text { grooves }\end{array}$ & No & $\begin{array}{l}\text { Around entire } \\
\text { brachial with left- } \\
\text { handed soiral }\end{array}$ \\
\hline Vadarocrinus & Broad, smooth & $\begin{array}{l}\text { Subtriangular, expand } \\
\text { distally }\end{array}$ & Unknown & No & Oral side \\
\hline
\end{tabular}



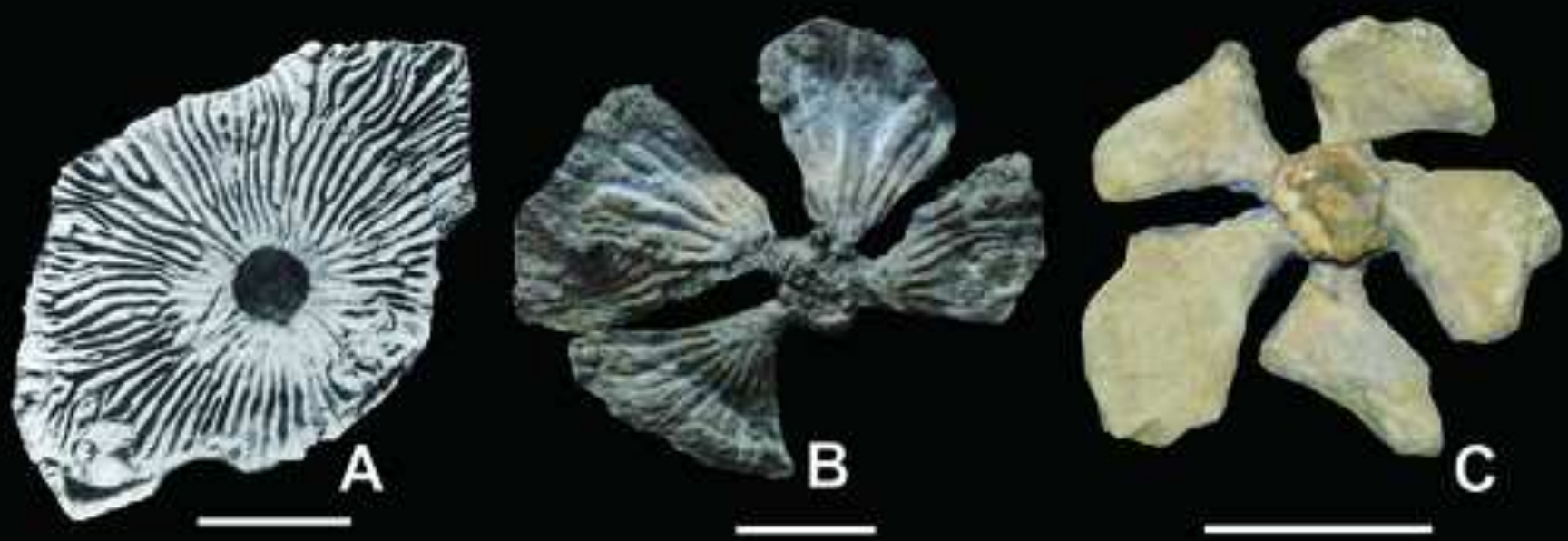

(III)(I) $E$

(Q(CE(ID) $) \mathrm{J}$

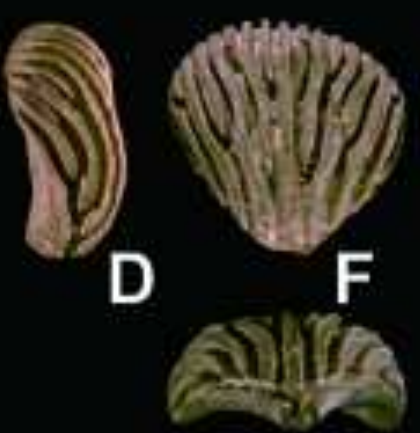

G
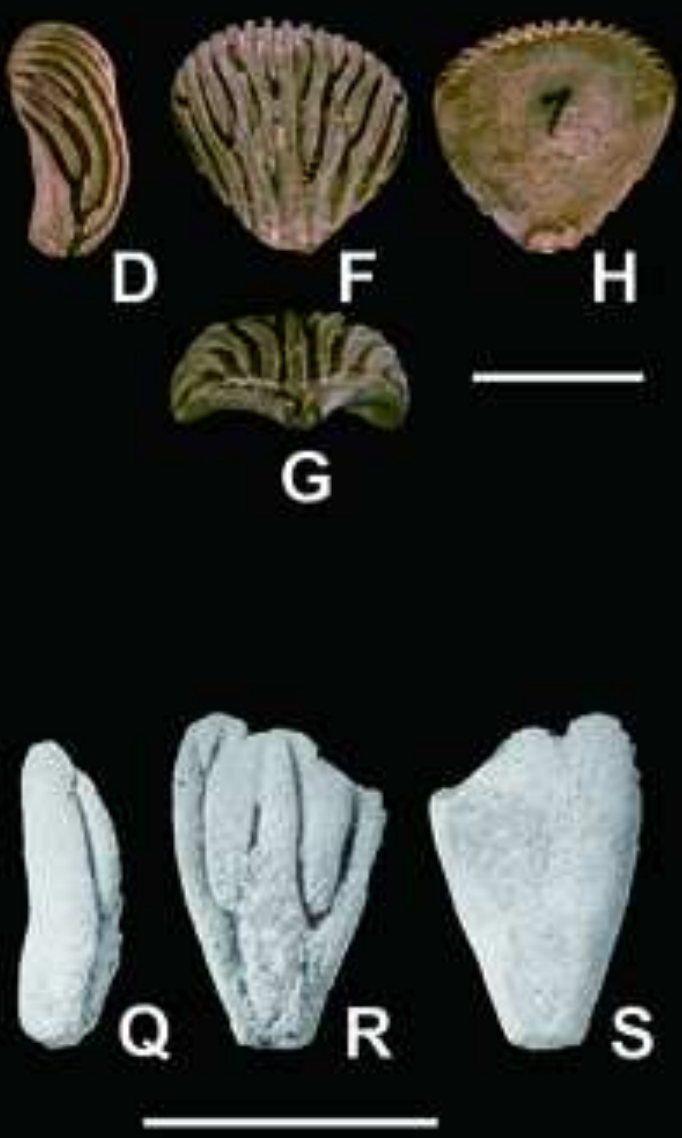

H

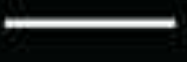

G
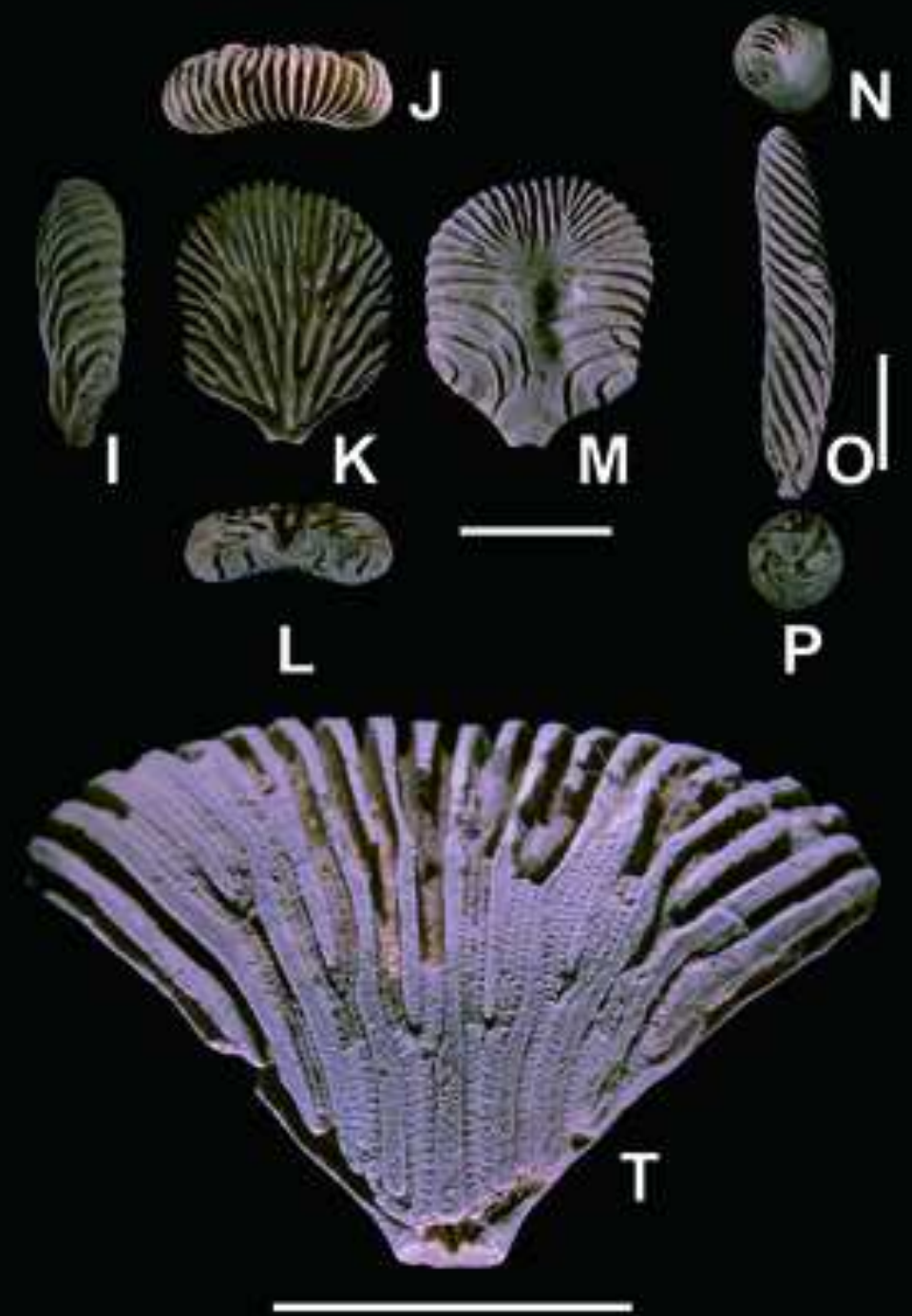
Figure 2

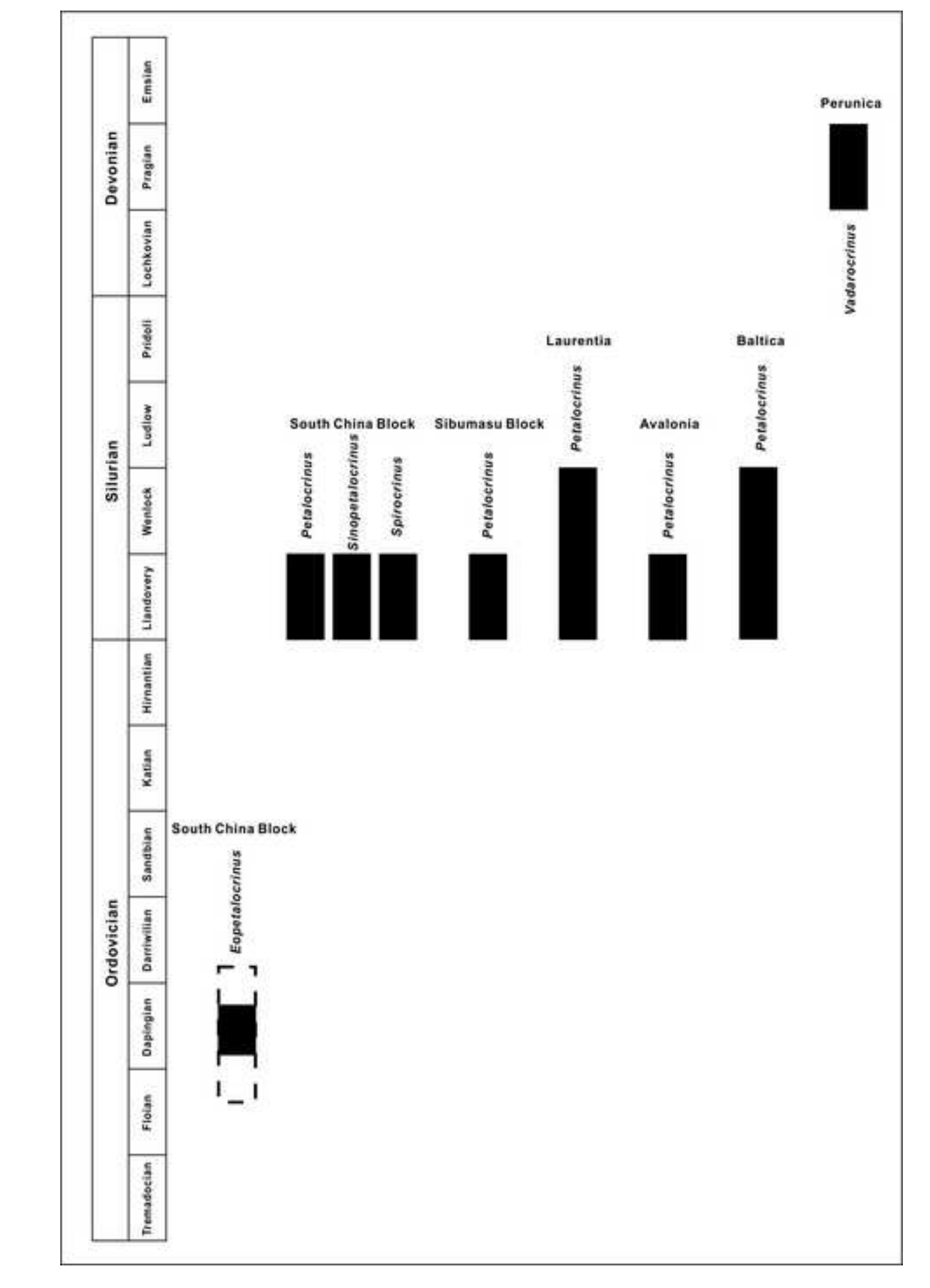

2

2




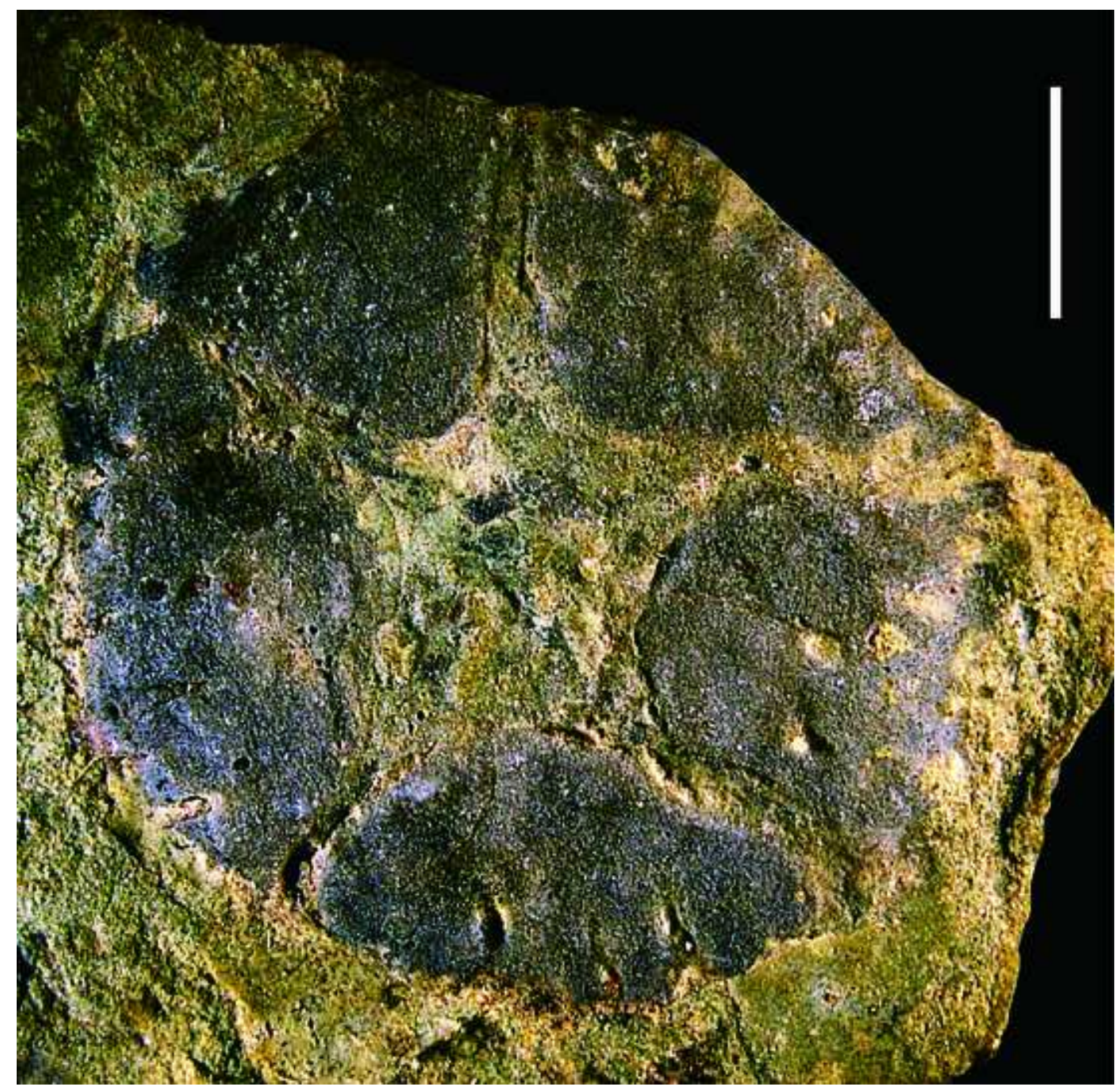

I.

(15)

6ring

Nots

(1)

1.

siver.

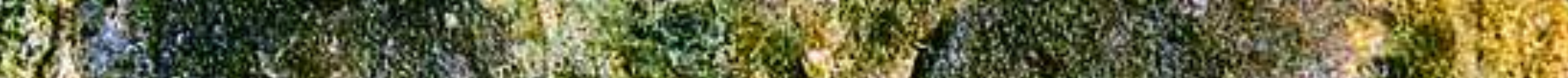

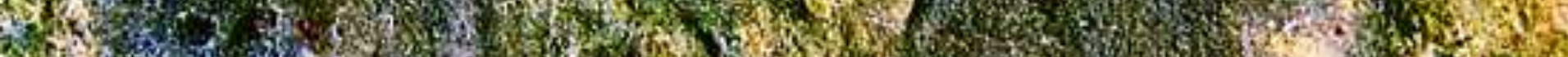

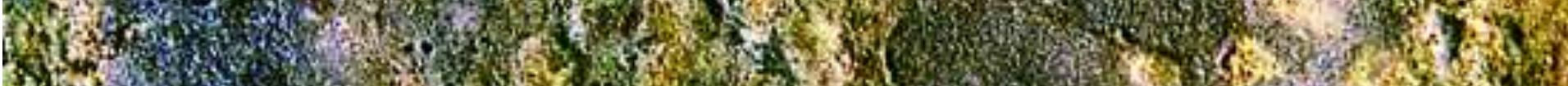
M.

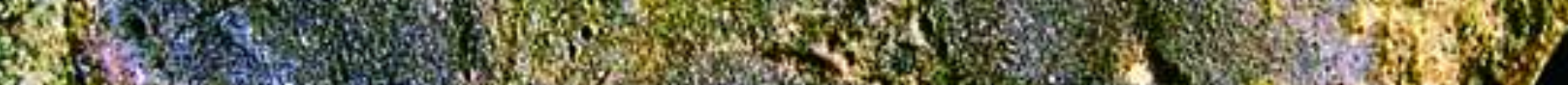
7. 7 .

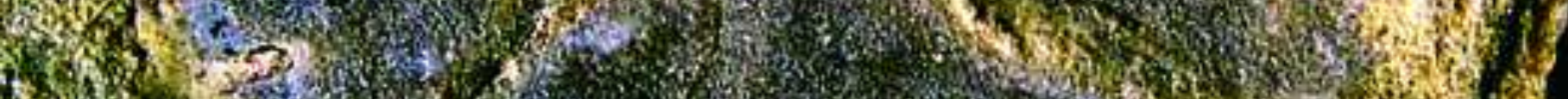

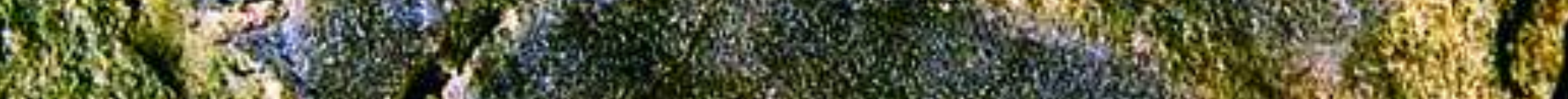

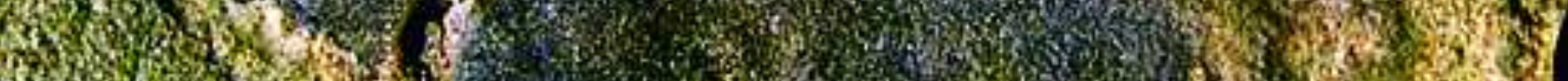

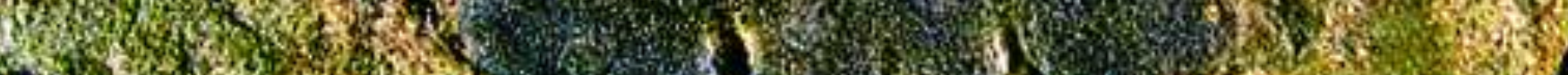

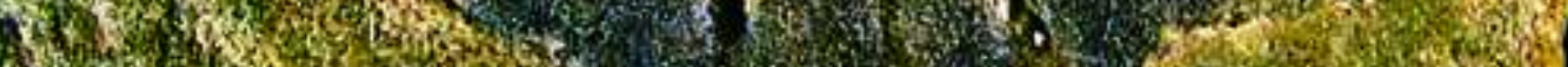
Q6 4.

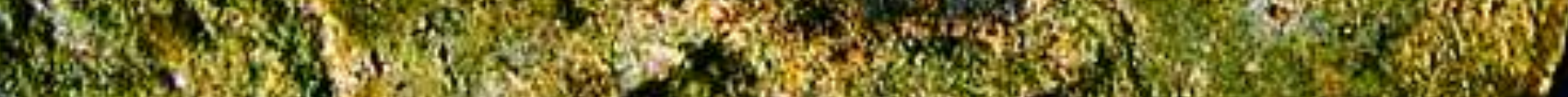

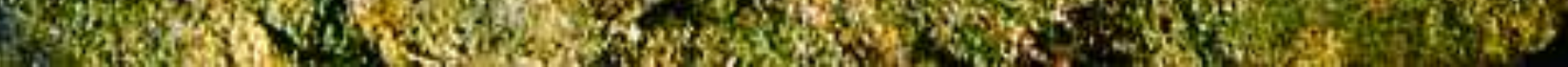

